\title{
GAEOLAELAPS INVICTIANUS, A NEW AND UNUSUAL SPECIES OF HYPOASPIDINE MITE (ACARI: MESOSTIGMATA: LAELAPIDAE) PHORETIC ON THE RED IMPORTED FIRE ANT SOLENOPSIS INVICTA BUREN (HYMENOPTERA: FORMICIDAE) IN LOUISIANA, USA
}

\author{
David Evans Walter ${ }^{1,2}$ and John C. Moser ${ }^{3}$ \\ 1. Department of Biological Sciences, University of Alberta, Edmonton, Alberta T6G 2E9, Canada; 2. Invertebrate \\ Zoology, Royal Alberta Museum, 12845-102 Avenue, Edmonton, Alberta T5N OM6, Canada \\ (e-mail: david.walter@gov.ab.ca); 3. USDA-Forest Service, Alexandria Forestry Center, 2500 \\ Shreveport Highway, Pineville, LA 71360,USA (e-mail: johnmoser@fs.fed.us).
}

(Received 22 January 2010; accepted 24 March 2010)

\begin{abstract}
A new species of hypoaspidine laelapid mite, Gaeolaelaps invictianus, associated with the red imported fire ant Solenopsis invicta Buren in the southern United States of America is described. This new species is unusual among the gamasine Mesostigmata in lacking a postanal seta in adults of both sexes and among species of Gaeolaelaps in being phoretic on dispersing male and female alate ants, lacking dorsal shield setae $z 3$ and $J I$, and in having a separate anal shield in the adult male. The chelicerae of this new species are similar to free-living forms, suggesting that it may be a predator of small invertebrates in the ant colony.

Key words - Laelapidae, Gaeolaelaps, invasive species, RIFA, phoresy, inquiline, Formicidae.
\end{abstract}

\section{INTRODUCTION}

Mites are relatively small animals, but one advantage of their diminutive size is that many are able to secure a living in association with even somewhat larger animals such as insects. Members of the suborder Mesostigmata are associated with numerous types of arthropods including ants (Hymenoptera: Formicidae): at least 20 families of mesostigmatans are associated with ants (Walter and Proctor, 1999). Among these are members of a number of genera in the family Laelapidae, some of which are considered to be myrmecophiles, such as species of Myrmozercon, Laelaspis, and Gymnolaelaps (Lindquist et al., 2009; Shaw and Seeman, 2009). Others, such as members of the genera Cosmolaelaps and Gaeolaelaps are mostly free-living or associated with a variety of other arthropods (Faraji and Halliday, 2009), but also can be found in soil collections from ant nests (Zeman, 1982; Beaulieu, 2009). In this paper we describe a new species of Gaeolaelaps discovered phoretic on dispersing winged adults (alates) of the red imported fire ant (RIFA) Solenopsis invicta Buren.

\section{MATERIALS AND METHODS}

Specimens were collected by hand by the junior author from 22 marked nests in a suburban yard in Pineville, Louisiana, USA. Alate ants were captured with forceps as they left the nest entrance and prepared for their nuptial flights (between 11:30 am and 3 $\mathrm{pm})$. At the time of collection, male and female ants were placed into separate $1 \mathrm{~mL}$ vials of ethanol and the mites were later recovered from the ants or the vials of alcohol. Mites were cleared in lactophenol and mounted on glass microscope slides in Berlese's medium for study. More details about collections may be found in Ebermann and Moser (2008). Photographs were taken on a Leica DM2500 DIC light microscope. Measurements are given in $\mu \mathrm{m}$ in parentheses as ranges or approximations (most setae attenuate to very fine tips that may bend, break off or be 
difficult to resolve even under oil immersion). Setal formula for femur I is tentative, owing to the noncylindrical form of the femur. Nomenclature follows Beaulieu (2009). Interpretation of setal losses follows from placement, the pattern of ontogenetic addition of setae described by Lindquist and Evans (1965), and the observation of Chant (1993) that setae that appear earlier in ontogeny tend to be more stable.

Type deposition - Holotype and paratypes will be deposited at the Types Collection Department, National Museum of Natural History (USNM), Smithsonian Institution, PO Box 37012, Washington, DC, 20013-7012, USA. Paratypes also will be deposited at the Royal Alberta Museum, Invertebrate Zoology (PMAE.IZ), 12845-102 Avenue, Edmonton, AB, T5N 0M6, Canada; Acarology Laboratory (OSAL), Museum of Biological Diversity, the Ohio State University, 1315 Kinnear Road, Columbus, OH 432112, USA; USDA-Forest Service, Alexandria Forestry Center (USDA-AFC), 2500 Shreveport Highway, Pineville, LA 71360; and the British Museum (Natural History), Cromwell Road, London SW7 5BD, United Kingdom.

\section{Family LAELAPIDAE Berlese, 1892 \\ Genus Gaeolaelaps Evans and Till, 1966 \\ Type species: Laelaps aculeifer Canestrini (1884), by original designation}

The various spellings (e.g. Geolaelaps) and authorship of Gaeolaelaps were recently elucidated by Halliday and Lindquist (2007) and the genus, currently with approximately 100 known species, was recently reviewed by Beaulieu (2009). In this paper, we are following the more expansive concept of Gaeolaelaps as defined by Beaulieu (2009), rather than the more restricted concept of Walter and Oliver (1989).

\section{Gaeolaelaps invictianus n. sp.} (Figs. 1-16)

DIAGNOSIS - Adults of both sexes with denticulate tectum; fixed digit of chelicera with row of 5-6 teeth; subcapitulum with 6 multidenticulate rows deutosternal denticles; anal shield with one pair of setae, postanal seta absent; dorsal shield seta $z 3$ and $J 1$ absent; $R$-series with a single seta; $U R$ series absent; sclerotized portions of the legs, gnathosoma, and body evenly adorned with spherical microtubercles ( $\leq 1 \mu \mathrm{m}$ diameter). Adult male with sternitogenitoventral shield eroded posteriorly, separate anal shield; 5 pairs ventral setae ( $J V 3, Z V 1, Z V 3$ absent).

Female $(n=17)$

CUTICLE - Soft cuticle plicate; sclerotized cuticle of the body and legs is uniformly covered in minute $(\leq 1 \mu \mathrm{m}$ diameter) spherical tubercles or pits (Figs. 8, 12).

DORSUM - (Fig. 1) Dorsal shield suboval $(512-570 \times 288-310$ at $r 2)$, with slight constriction in the $s 6-S 2$ region, evenly rounded posteriorly, about $1.8 \times$ as long as wide), evenly microtuberculate throughout, weakly reticulate posteriorly, and bearing 37 pairs of mostly acicular setae with attenuate tips, but J4-5, Z5 sparsely barbed; anterior region with 21 pairs of setae (j1-6; z1-2 [ $z 3$ absent], 4-6; s1-6; r2-5); posterior region with 16 pairs of setae $(\mathrm{J} 2-5[\mathrm{JI}$ absent]; Z1-5, S1-5, px2-3); approximate lengths: $j 1$ (30-33), j2 (34-35), j3 (42-47), j4 (42), j5 (42) j6 (46); $z 1$ (32-35), z2 (38), z4 (47), z5 (46), z6 (41); s1 (35), s2 (35), s3 (48), s4 (42), s5 (48), s6 (43); r2 (40), r3 (44), r4 (35), r5 (41); J2 (46-47), J3 (46), J4 (45), J5 (42-45); Z1 (50), Z2 (45), Z3 (46), Z4 (44), Z5 (45-52); S1 (36$42), S 2$ (42-44), $S 3$ (39-45), $S 4$ (42), $S 5$ (43-45). R1 in soft cuticle; $U R$ setae absent.

PERITREMATAL SHIELD - (Fig. 2) Micropunctate, narrow, joins dorsal shield near $z 1$, extends to mid-region coxa IV posteriorly, free from parapodal elements; peritreme extends anteriorly to about level of $j 2$ (Fig. 1).

TECTUM - Procurved, margin irregularly denticulate (Fig. 4).

SUBCAPITULUM - With a row of 4 rectangular cells on either side of the deutosternal groove; 6 multidenticulate (10-20) rows of denticles (Fig. 9), plus anterior and posterior smooth ridges; hypostomal setae acicular, attenuating distally, $h l$ (38-40), $h 2$ (outer) (21-23), h3 (45-46), pc (25-26); corniculi (max. outer length 43-45) simple, horn-like, extending just beyond anterior margin of palptrochanter (Fig. 11); internal malae densely pilose ventrally (Fig. 10).

CHELICERAE - (Figs. 5, 11) Movable digit (68-70) bidentate; middle article (147-157); fixed digit with row of 5 (rarely 6) teeth + offset tooth (gabelzahn); pilus dentilis (8-10) setiform, longer than any of the teeth; cheliceral seta (9-10) flattened; arthrodial corona fringe-like, processes longest (13-15) in midregion.

PALPS - Extended ( -190 long) reach to base of movable digit on fully extended chelicerae (Fig. 11), $\sim 1.25 \times$ length of middle cheliceral article. Setation of trochanter, femur, genu, tibia, tarsus: 2-5-6-14-15; palp apotele 2-tined, each tine with hyaline margin (Fig. 3). Median setae of palpgenu not broadened or toothed distally: all short (11-13), spine-like; al2 longer ( 20$)$, blunt, \pm blade-like; al of palpfemur similar but longer ( 25$)$; other setae of palp femur, genu, and tibia acicular, attenuating.

VENTER - (Fig. 2) Ventral setae acicular with attenuate tips. Sternal shield (Figs. 2, 8) membranous anteriad $s t 1$, notched posteriad tritosternal base forming 


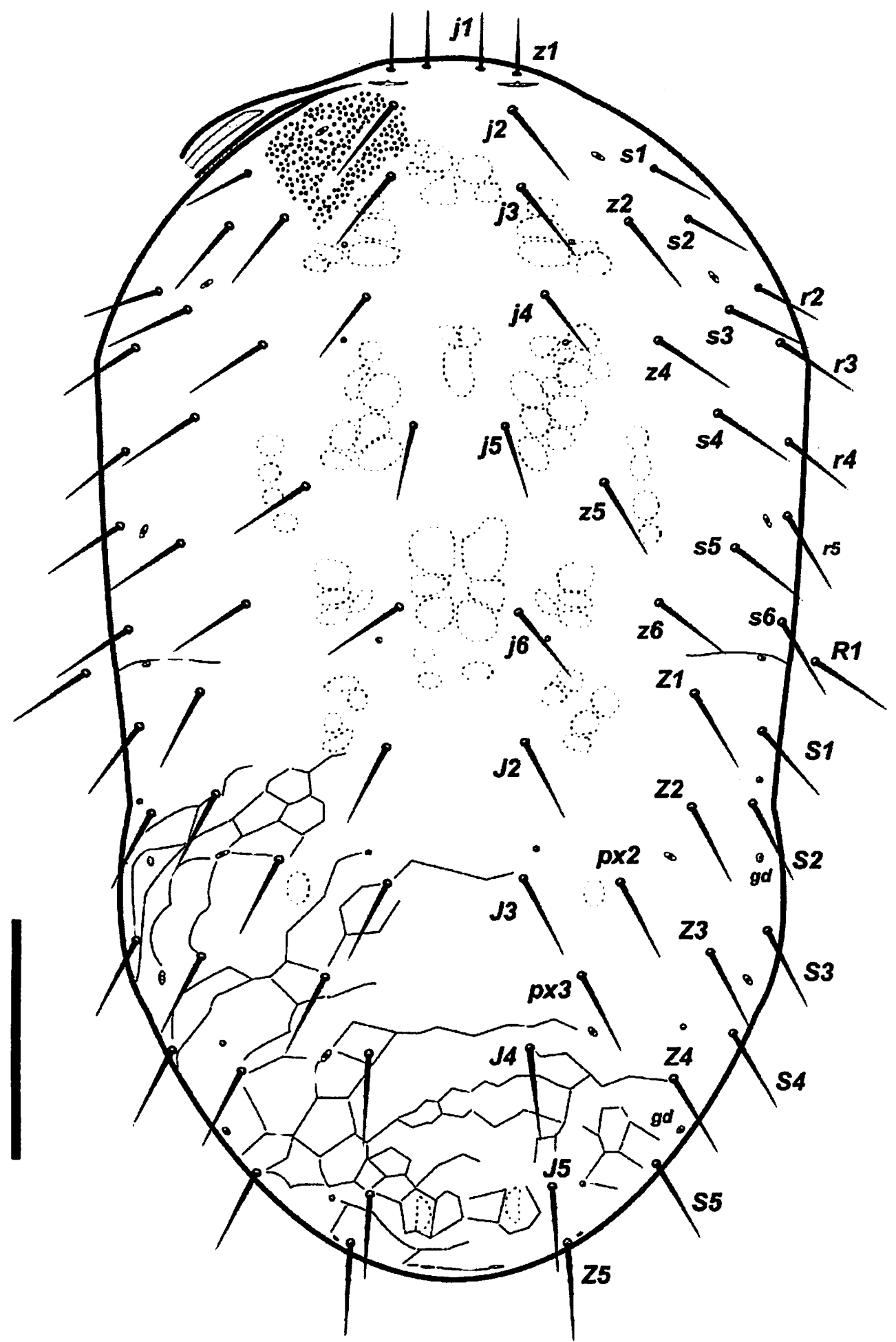

Fig. 1. Gaeolaelaps invictianus n. sp., adult female: dorsal shield. Scale bar $=0.1 \mathrm{~mm}$. 


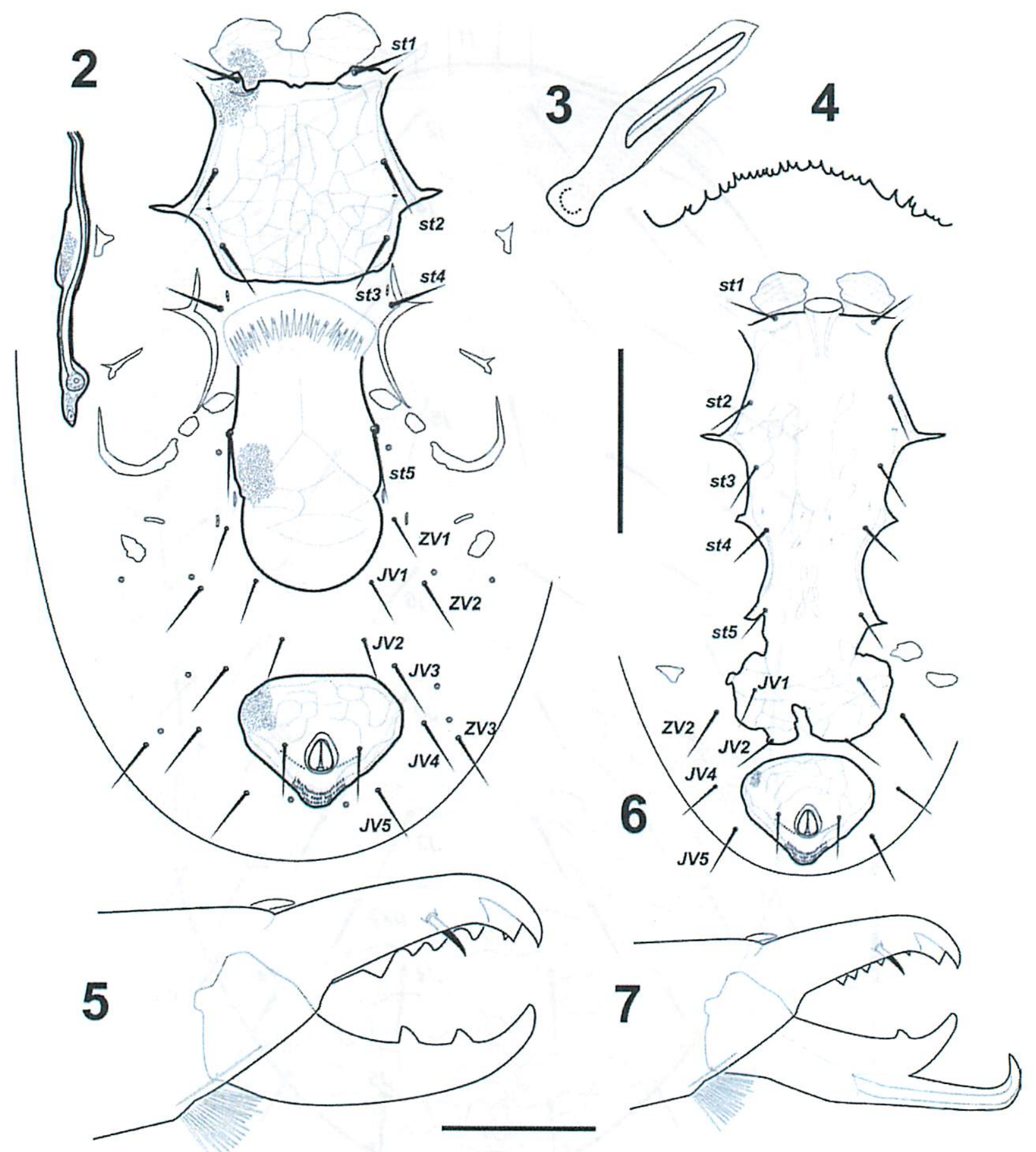

Figs. 2-7. Gaeolaelaps invictianus n. sp., adult female: 2. venter; 3. palpal apotele; 4. gnathotectum; 5. chelicera, antiaxial view; adult male; 6 . venter; 7. chelicera. Scale bars $=0.1 \mathrm{~mm}(2,6) ; 50 \mu \mathrm{m}(5,7) ;(3,4)$ not to scale. 

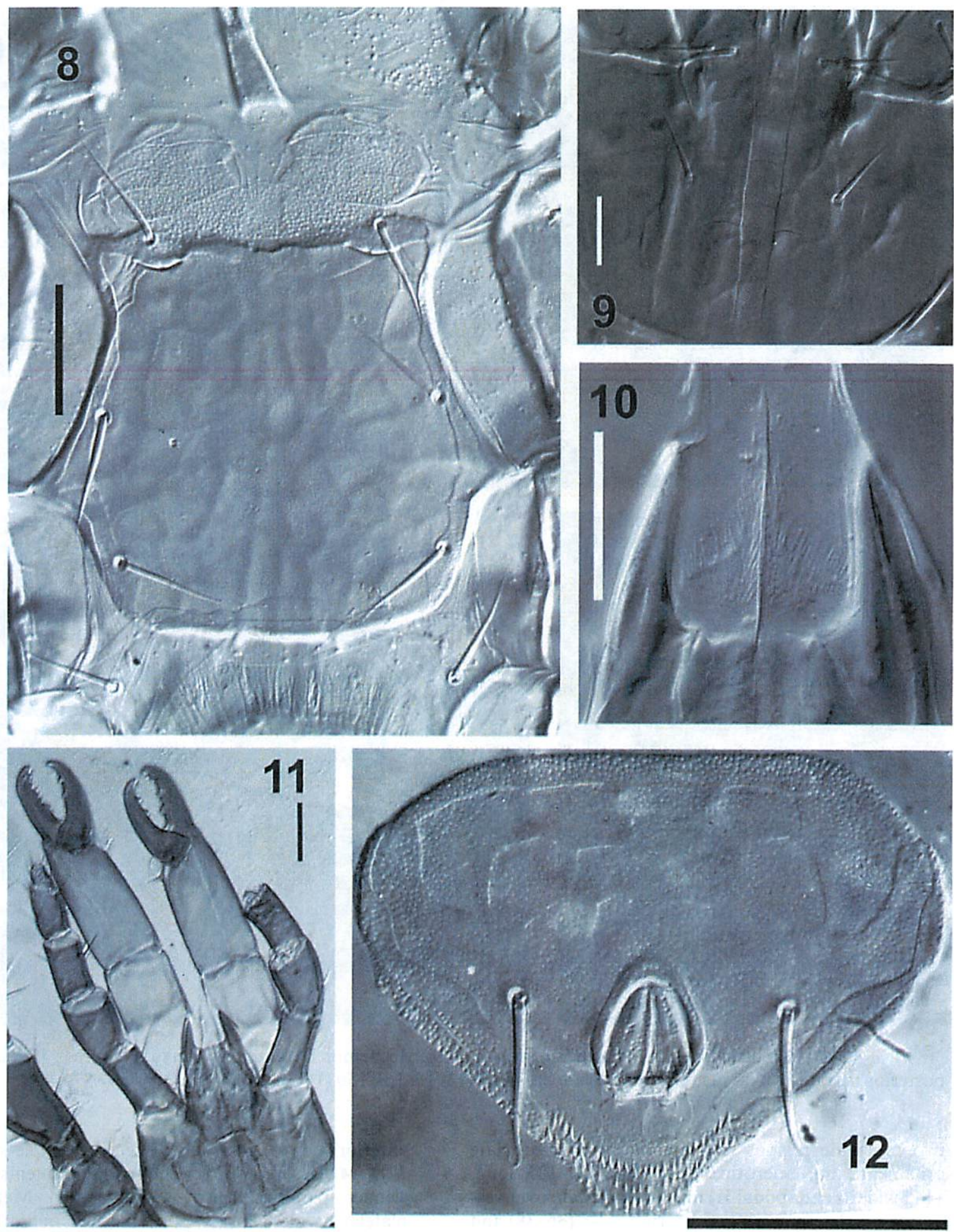

Figs. 8-12. Gaeolaelaps invictianus n. sp., adult female: 8. sternal shield; 9. subcapitulum; 10. corniculi and internal malae; 11. gnathosoma, ventral view; 12. anal shield. Scale bars $20 \mu \mathrm{m}(9,10) ; 40 \mu \mathrm{m}(8,11,12)$. 

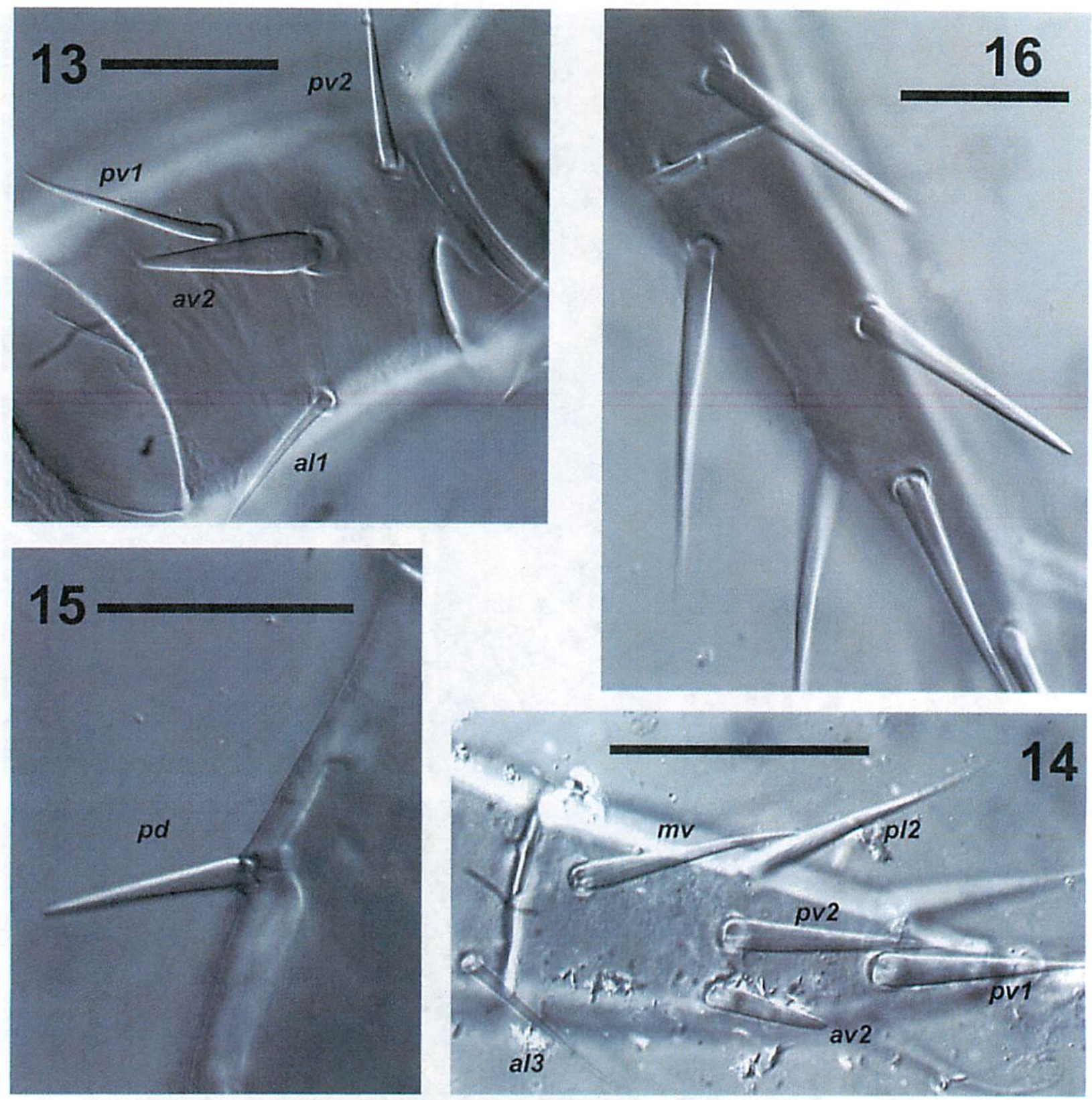

Figs. 13-16. Gaeolaelaps invictianus $\mathbf{n}$. sp., adult female: 13. femur II venter; 14. tarsus II venter; 15. femur IV posterior margin; 16. tarsus IV venter. Scale bars $=30(13,15,16), 150(14) \mu \mathrm{m}$.

two reticulate regions overlain by microtuberculate ornamentation; sclerotized portion (120-125 long, $\sim 145$ wide at endopodal II) microtuberculate over vestigial reticulate pattern and bearing st 1-3 (36-38) and iv 1-2; sternal setae simple, subequal (38-43); posterior margin of shield irregular; st4 (38) similar, in soft cuticle with $i v 3$. Epigynal shield micropunctate, membranous anteriorly, \pm tongue-shaped, bearing simple st 5 (30$32) ; i v 4$ in soft cuticle. Endopodal elements III-IV slender, parapodal element fragmented. Metapodal platelet divided, larger portion $(\sim 25)$ microtuberculate, fragment $(\sim 8)$ linear. Anal shield (Figs 2, 12) (7782 long $\times 95-100$ wide) subcordate, weakly reticulate under microtubercles, with anal opening strongly 
projecting ventrally; paranal setae (35) simple, postanal seta absent; cribrum terminal, 3-4 rows of processes. Eight pairs (JVI-5, ZVI-3) simple ventral setae (35-43) in soft cuticle. Tritosternum with basal stalk (30) and 2 fringed laciniae ( -85$)$ joined at base. Female secondary sperm access system not visible.

LEGS - All tarsi with ambulacra; most leg setae acicular with strongly tapering tips, distal setae of tarsi II-IV thicker at base, tending to be worn distally. Modified setae on legs II, IV: femur II av2 (28-29) thick, spur-like (Fig. 13), tarsus II av2 short (15-18), blunt; pv2 longer (30-34), spine-like (Fig. 14); femur IV $p d$ (25-29) slender, spur-like (Fig. 15); tibia IV $p v$ (35-38) spur-like; basitarsus IV al3, telotarsus IV a ventral seta both blunt, spine-like (37-40) (Fig. 16). Setal counts of leg segments I-IV, respectively: coxae 2-2-2-1; trochanters 6-5-5-5; femora 13-11-6-6; genua I-IV: 13-11-9-9; tibiae 13-10-8-10. Setal formulas (al-adlav, $p d l p v-p l$ ) for leg segments I-IV, respectively: femora $2-3 / 2,2 / 2-2 ; 2-3 / 2,2 / 1-1 ; 1-2 / 1$, $1 / 0-1 ; 1-2 / 1,1 / 0-1$; genua $2-3 / 2,3 / 1-2 ; 2-3 / 1,2 / 1-2$; $2-2 / 1,2 / 1-1 ; 2-2 / 1,3 / 0-1$; tibiae $2-3 / 2,3 / 1-2 ; 2-2 / 1,2 /$ $1-2 ; 2-1 / 1,2 / 1-1 ; 2-1 / 1,3 / 1-2$.

Male - Similar to the female except: movable digit of chelicera unidentate and with relatively thick, hooked spermatodactyl (Fig. 7); venter (Fig. 6) with sternitogenitoventral shield with weak reticulate ornamentation, irregular eroded posterior and posterolateral margins, bearing 7 pairs of setae (st $1-5, J V l-2)$ and 5 pairs of pore-like structures; $Z V 2, J V 4-5$ in soft cuticle; ventral setae $J V 3, Z V I, Z V 3$ absent; metapodal platelets divided, median portion free or fused to ventral region of shield.

Material examined - Holotype female: ex alate male Solenopsis invicta Buren, Pineville, LA, USA, 29.v.2005, J. Moser (slide\# 47,760) in USNM; 16 female paratypes ex male and female alate $S$. invicta, Pineville, LA, USA, 1.vi.2004 (slide\# 46, 560), 2931.v.2005 (slide\# 47: 576, 713, 725, 736, 762, 765, 871, 878, 914, 988, 963, 992), 2.vi.2005 (slide\# 48: 097, 103), vii.2005 (slide\# 48,405); 2 male paratypes same data (slide\# 46,569; 48,394), all collections J. Moser, in USNM, PMAE.IZ, OSAL, USDA-AFC.

Remarks - Although this new species has the general facies of a species in the genus Gaeolaelaps, its unusual reductions in setation make its placement tentative. Loss of the postanal seta is characteristic of the Cercomegistina (where it is present in the larva, but absent in subsequent stages), but such a loss is very rare in other Mesostigmata and unknown in other Laelapidae (Lindquist et al., 2009). Although the other setal reductions in $G$. invictianus are unusual, they are known in some species in the genus. For example, Gaeolaelaps brevior Faraji and Halliday, 2009; G. ruggi Strong and Halliday, 1994; and G. variabilis Faraji and Halliday, 2009, also lacks seta $z 3$ and $J l$ may be missing asymmetrically from the latter (Faraji and Halliday, 2009). At least two other species of Gaeolaelaps have males with separate anal shields: $G$. negevi Costa, 1969, and G. schusteri Hirschmann, 1961 (Costa, 1974).

\section{DISCUSSION}

The RIFA is an invasive species in North America that has a suppressive effect on native ants, but it is primarily restricted to habitats with a high level of human disturbance (King and Tschinkel, 2008). Previously, the only mesostigmatan described in association with the RIFA in North America was Gymnolaelaps shealsi Hunter and Costa, 1971, but several new species of Heterostigmatina (Prostigmata) have been described from fire ant alates in Louisiana (Ebermann and Moser, 2008; Khaustov and Moser, 2008).

The best known species of Gaeolaelaps are generalist predators including several that are useful in biological control (Walter and Oliver, 1989; Beaulieu, 2009); however, numerous species have been described in association with arthropods, especially those that make nests or form burrows in soil or logs (e.g. cockroaches, passalid beetles). Little is known about the association between Gaeolaelaps species and other arthropods, but in perhaps the best known system the mites may be associated with only one or with several species of Australian cockroaches (Strong and Halliday, 1994; Faraji and Halliday, 2009).

Although species of Gaeolaelaps have been found associated with ants (Zeman, 1982; Beaulieu, 2009), this appears to be the first record of one that is phoretic on alate ants and the association appears to be a strong one (Fig. 17). Most of the phoretic individuals were adult female mites and only rarely were males found; however, both male and female alate ants were used as phoretic carriers. Since only female alate ants found new colonies, the lack of preference in the mites could indicate a recent association with the ants. Alternatively, the use of male ant carriers may indicate that venereal transmission of the mites from males of one colony to females from another is possible. Although the ability to hitch a ride on dispersing adult ants raises the possibility of a more intimate association with ants, the chelicerae have no obvious modifications that would suggest that $G$. invictianus n. sp. deviates from its ancestral feeding biology. Thus, we suspect that it may act as a generalist predator-inquiline in the ant colony.

Another potentially informative aspect of G. invictianus n. sp. is its loss of setae usually found in free-living members of the genus. These losses are of 


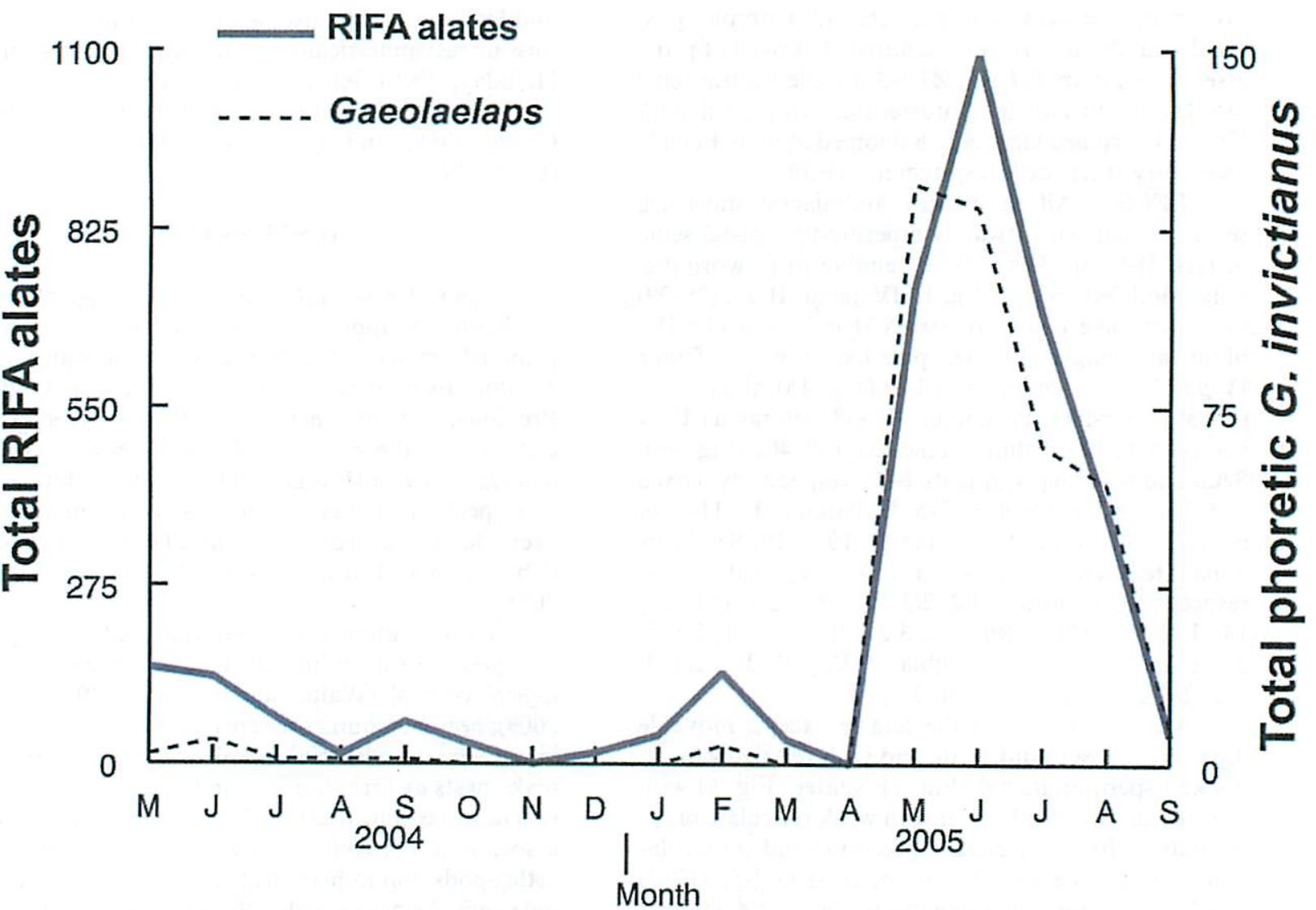

Fig. 17. Monthly totals for alates of the red imported fire ant (RIFA) Solenopsis invicta and phoretic individuals of Gaeolaelaps invictianus $\mathbf{n}$. sp.

two types. The first is setae usually added later in ontogeny: $J 1$ is usually added in the protonymph while $z 3, R 2-x$, and the $U R$-series are usually added in the deutonymph (Lindquist and Evans, 1965). Similar ontogenetic reductions in mechanoreceptor setae are often found in arthropod-associated species of Gaeolaelaps (e.g. Hunter and Yeh, 1969; Faraji and Halliday, 2009; and see Beaulieu, 2009), possibly as a result of accelerated development or reduced environmental interactions in a nest or burrow.

The RIFA is a classic invasive species, but the origin of G. invictianus $\mathbf{n}$. sp. is more ambiguous than that of its host. One key to elucidating its origin may be the unusual suppression of the postanal seta: this character state is unknown in any other described Gaeolaelaps and as far as we have been able to determine is not known in other Gamasina. If other species lacking the postanal seta are found, e.g. in the poorly known fauna of South America, then that would suggest that this new species of mite, like its host the RIFA, is a recent colonist of North America.

\section{ACKNOWLEDGEMENTS}

We thank Stacy Blomquist for her always excellent work mounting and curating the collections and Fred Beaulieu for his help and suggestions.

\section{REFERENCES}

Beaulieu, F. 2009. Review of the mite genus Gaeolaelaps Evans \& Till (Acari: Laelapidae), and description of a new species from North America, G. gillespiei n. sp. Zootaxa. 2158: 33-49.

Chant, D. 1993. Paedomorphosis in the family Phytoseiidae (Acari: Gamasina). Can. J: Zool. 71: 1334-1349.

Costa, M. 1974. Mesostigmatic mites (Acari: Mesostigmata) from the Mediterranean shores of Israel. 1. The genus Hypoaspis Canestrini 1884. Israeli J. Entomol. 9: 219-227.

Ebermann, E. and J. C. Moser. 2008. Mites (Acari: Scutacaridae) associated with the red imported 
fire ant, Solenopsis invicta Buren (Hymenoptera: Formicidae), from Louisiana and Tennessee, USA. Internat. J. Acarology. 34: 55-69.

Faraji, F. and B. Halliday. 2009. Five new species of mites (Acari: Laelapidae) associated with large Australian Cockroaches (Blattodea: Blaberidae). Internat. J. Acarology. 35: 245-264.

Halliday, R. B. and E. E. Lindquist. 2007. Nomenclatural notes on the names Gaeolaelaps and Geolaelaps (Acari: Laelapidae). Zootaxa. 1621: 65-67.

Hunter, P. E. and S. Yeh. 1969. Hypoaspis (Geolaelaps) disjuncta n. sp. (Acarina: Laelapidae) associated with the horned passalus beetles. J. Ga Entomol. Soc. 4: 97-102.

Khaustov, A. A. and J. C. Moser. 2008. Two new species of mites of the genera Petalomium Cross and Caesarodipsus Mahunka (Acari: Heterostigmata: Neopygmephoridae, Microdipsidae) associated with Solenopsis invicta Buren (Hymenoptera: Formicidae) from the USA. Internat. J. Acarology. 34: 115-121.

King, J. R. and W. R. Tschinkel. 2008. Experimental evidence that human impacts drive fire ant invasions and ecological change. Proc. Nat. Acad. Sci. 105(51): 20339-20343.

Lindquist, E. E. and G. O. Evans. 1965. Taxonomic concepts in the Ascidae, with a modified setal nomenclature for the idiosoma of the Gamasina
(Acarina: Mesostigmata). Mem. Entomol. Soc. Can. 47: 1-64.

Lindquist, E. E., G. W. Krantz, and D. E. Walter. 2009. Order Mesostigmata. pp. 124-232. In: Krantz, G. W. and D. E. Walter (Eds.). A Manual of Acarology. 3rd ed. Texas Tech University Press, Lubbock, TX, USA. 807 pp.

Shaw, M. D. and O. D. Seeman. 2009. Two new species of Myrmozercon (Acari: Laelapidae) from Australian ants (Hymenoptera: Formicidae). Zootaxa. 2025: 43-55.

Strong, K. L. and R. B. Halliday. 1994. Three new species of Hypoaspis Canestrini (Acarina: Laelapidae) associated with large Australian cockroaches. J. Aust. Entomol. Soc. 33: 87-96.

Walter, D. E. and J. H. Oliver, Jr. 1989. Geolaelaps oreithyiae, n. sp. (Acari: Laelapidae), a thelytokous predator of arthropods and nematodes, and a discussion of clonal reproduction in the Mesostigmata. Acarologia. 30: 293-303.

Walter, D. E. and H. C. Proctor. 1999. Mites: Ecology, Evolution and Behaviour. University of NSW Press, Sydney, Australia and CABI, Wallingford, UK. 322 pp.

Zeman, P. 1982. Two new species of Hypoaspidinae (Acari: Mesostigmata: Dermanyssidae) associated with ants. Vestn Cesk. Spol. Zool. 46: 231-237. 
This article was downloaded by: [National Center for Animal Health]

On: 17 November 2010

Access details: Access Details: [subscription number 919567189]

Publisher Taylor \& Francis

Informa Ltd Registered in England and Wales Registered Number: 1072954 Registered office: Mortimer House, 3741 Mortimer Street, London W1T 3JH, UK

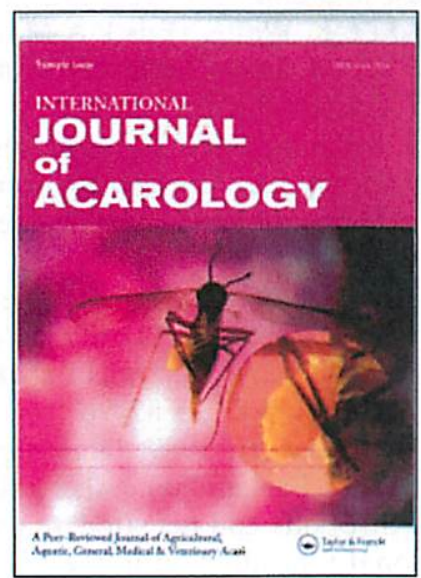

International Journal of Acarology

Publication details, including instructions for authors and subscription information:

http://www.informaworld.com/smpp/title $\sim$ content=t795426017

Gaeolaelaps invictianus, a new and unusual species of hypoaspidine mite (Acari: Mesostigmata: Laelapidae) phoretic on the red imported fire ant Solenopsis invicta Buren (Hymenoptera: Formicidae) in Louisiana, USA David Evans Walter ${ }^{\text {ab }}$; John C. Moser

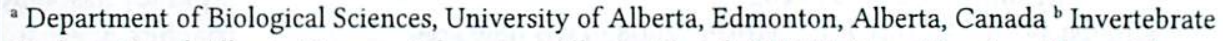
Zoology, Royal Alberta Museum, Edmonton, Alberta, Canada ${ }^{\mathrm{c}}$ USDA-Forest Service, Alexandria Forestry Center, Pineville, LA, USA

Online publication date: 29 October 2010

To cite this Article Walter, David Evans and Moser, John C.(2010) 'Gaeolaelaps invictianus, a new and unusual species of hypoaspidine mite (Acari: Mesostigmata: Laelapidae) phoretic on the red imported fire ant Solenopsis invicta Buren (Hymenoptera: Formicidae) in Louisiana, USA', International Journal of Acarology, 36: 5, 399 - 407

To link to this Article: DOI: $10.1080 / 01647954.2010 .481263$

URL: http://dx.doi.org/10.1080/01647954.2010.481263

\section{PLEASE SCROLL DOWN FOR ARTICLE}

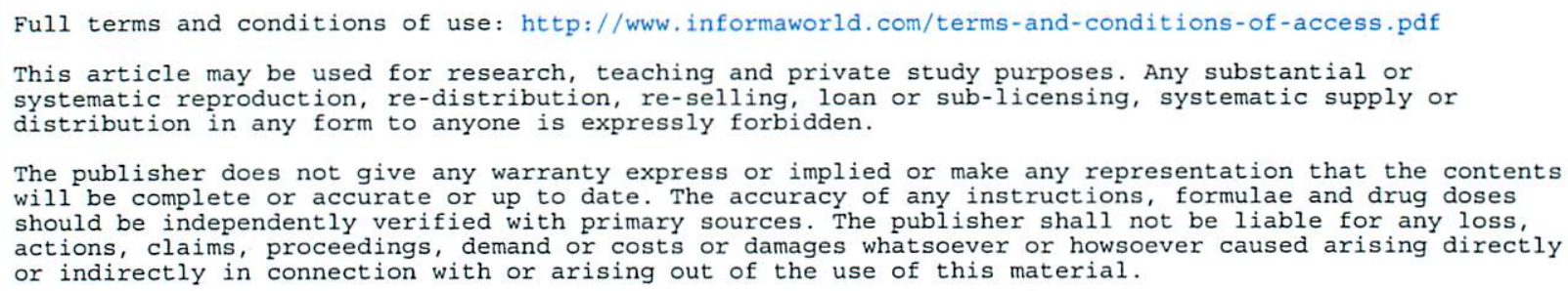

